\section{BOLLETTINO DELLA \\ SOCIETA CEOCRAFICA ITALIANA}

OPEN ACCESS

Citation: O. Albolino, L. Cappiello (2020). Matera: the Sassi through Trade, Consumption and Tourism. Bollettino della Società Geografica Italiana serie 14, 3 Special Issue: 51-61. doi: 10.36253/ bsgi-990

Copyright: (c) 2020 O. Albolino, L. Cappiello. This is an open access, peerreviewed article published by Firenze University Press (http://www.fupress. $\mathrm{com} / \mathrm{bsgi}$ ) and distributed under the terms of the Creative Commons Attribution License, which permits unrestricted use, distribution, and reproduction in any medium, provided the original author and source are credited.

Data Availability Statement: All relevant data are within the paper and its Supporting Information files.

Competing Interests: The Author(s) declare(s) no conflict of interest.

For Italian evaluation purposes: Although this paper is the result of the joint research of the two authors, the paragraphs 1 is to be attributed to both, the paragraphs 1.1 and 3 to Lucia Cappiello, the paragraphs 2 and 4 to Ornella Albolino. It should be pointed out that in this case study the research survey was interrupted at the end of 2019 for the well-known events related to the current sanitary emergency.
Firenze University Press

www.fupress.com/bsgi

\title{
Matera: the Sassi through Trade, Consumption and Tourism
}

\section{Matera: i Sassi tra commercio, consumo e turismo}

\author{
Ornella Albolino ${ }^{1}$, Lucia Cappiello ${ }^{2}$ \\ ${ }^{1}$ Dipartimento di Scienze Umane, Università degli Studi della Basilicata \\ ${ }^{2}$ Dipartimento delle Culture Europee e del Mediterraneo, Università degli Studi della \\ Basilicata \\ E-mail: ornella.albolino@unibas.it; lucia.cappiello@unibas.it
}

\begin{abstract}
The European Capital of Culture (ECoC) process-event has contributed to amplify the main transformations of the commercial structure in Matera. This paper proposes an analysis of the recent transformation of the historical Sassi neighborhood, aimed at pointing out the changes in trade and consumption practices, considering the effects that the development of tourism, one among the main drivers of the changes occurred, has produced in this area. Indeed, the Sassi neighborhood represents a definitely peculiar commercial and touristic landscape: from the year of designation of Matera as ECoC until today, the neighborhood - already a privileged destination for local tourism - has invested in a decisive reconversion of its commercial spaces, focused on the food \& drink segment. These commercial activities are addressed mainly for tourists, therefore the first and most evident result is, actually, the exclusion of the residents. What are the characteristics of such a touristic change? What is the position of these places in the urban context? What are the functions that characterize them? Attempting to answer these questions will enable to highlight the specific characteristics of the Sassi and their development based on the most remarkable forms of touristification.
\end{abstract}

Keywords: historical neighborhood, trade, consumption, tourism development.

Riassunto. Il processo-evento Capitale Europea della Cultura (ECoC) ha contribuito ad amplificare le principali trasformazioni della struttura commerciale di Matera. Il contributo propone un approfondimento sull'evoluzione recente dello storico quartiere dei Sassi, volto a far emergere i cambiamenti nelle pratiche di commercio e consumo, alla luce degli effetti che lo sviluppo turistico, tra i principali motori dei mutamenti avvenuti, ha prodotto in questi luoghi. I Sassi presentano infatti un paesaggio commerciale e turistico decisamente peculiare: dall'anno della designazione di Matera ad ECoC ad oggi, l'area - già meta privilegiata del turismo di prossimità - ha investito in una decisa riconversione dei suoi spazi commerciali, concentrandoli nella tipologia del food \& drink. Rivolgendo simili attività quasi esclusivamente ai turisti, il primo e più evidente risultato è l'esclusione, di fatto, dei residenti. Quali le caratteristiche di una tale trasformazione in chiave principalmente turistica? Quale la collocazione di questi luoghi nella realtà urbana? Quali le funzioni che li connotano? Tentare di rispondere a tali quesiti consentirà di far emergere le specificità dei Sassi e del loro sviluppo improntato alle più spiccate forme di turistificazione. 
Parole chiave: quartiere storico, commercio, consumo, sviluppo turistico.

\section{Premise: memory and souvenirs}

The case study focuses on the Sassi of Matera and aims, as main objective, at highlighting the most significant and recent transformations that have characterized the area examined, from the point of view of trade and, in part, of consumption. From this point of view, the theoretical assumptions concern the relationship between urban spaces, commerce and consumption: analyzing these issues permits to understand the extent and rapidity of the changes occurring, in order to "build knowledge that results in appropriate policies, in connection with the social body involved" (Viganoni 2019b, $10)^{1}$.

Particular attention is paid to the impact of tourism development on urban spaces and, specifically, on the historical centres with their valuable cultural heritage. Especially in order to promote more suitable policies, starting from a deep knowledge of local context, trying to outline conditions of economic, social, as well as environmental sustainability, thus ensuring the well-being of communities, avoiding conflictual situations. More generally, the paper contributes to the analysis of the new relationship between cities and tourism (Adamo 2012), a perspective that is also developed through European programmes that enhance the urban-cultural, material and immaterial heritage, with the asset of the big events (Richards, Palmer 2010).

The event-process Matera European Capital of Culture (ECoC) 2019 (D’Alessandro, Stanzione 2018) has, in fact, strengthened the role of the city as tourist destination (Stanzione, Viganoni 2012), accelerating a number of changes, in part already underway within the urban fabric. This has happened exponentially within the Rioni Sassi, a UNESCO heritage site and main tourist attraction of Matera. Often, however, the changes that have occurred do not represent the product of a shared vision and, therefore, negative externalities are emerging, affecting mainly the residents (García 2004). In Matera, tourism has modified

\footnotetext{
1 The changes result in the "food and tourism-led transformation marked by rapidity and volatility" (Viganoni 2019b, 24). See the research activity related to PRIN 2015 Commercio, consumo e città: pratiche, pianificazione e governance per l'inclusione, la resilienza e la sostenibilità urbane, coordinated by L. Viganoni, who defined the basic theoretical and methodological framework (Viganoni 2017, 2019a). See also the works of Cirelli 2007 and D'Alessandro 2015
}

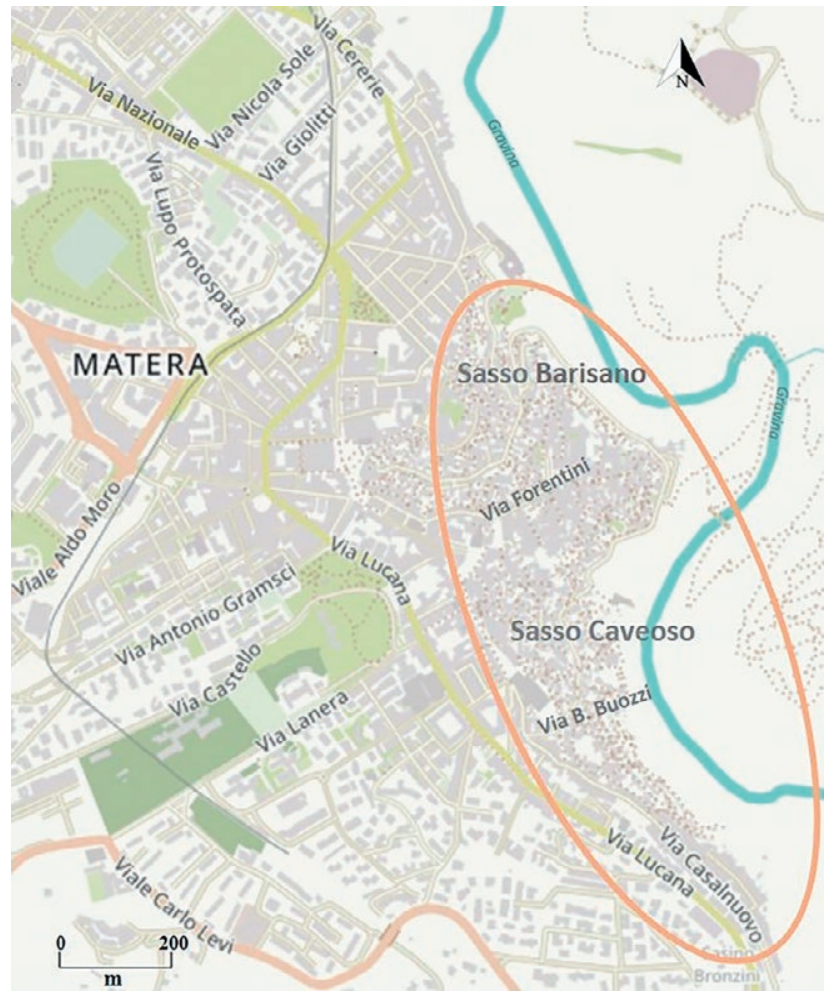

Figure 1. Matera and the Rioni Sassi. Source: authors' elaboration from OpenStreetMap 2019.

the structure and characteristics of the city and, above all, those of a neighbourhood such as the Sassi, where one of the most evident aspects is the proliferation of accommodation and food \& drink activities, mostly conceived for tourists (Finkelstein 1999).

In detail, after a description of the main elements that define the origin and evolution of the Rioni, the contribution underlines the Sassi as an example of deterritorialization of the living function and re-territorialization of the commercial spaces in a tourist-oriented key (Kärrholm 2012). Mainly starting from 2015 until today, there has been a deep metamorphosis of the commercial landscape in the Sassi as a direct consequence of tourism development. This phenomenon has accentuated the dichotomy between the rest of the city and the district, which has consolidated its tourist function, while facing the risk of triggering processes of so-called "trullizzazione" 2 (Stanzione 2009, 8; Semi 2015).

\footnotetext{
2 These aspects have also emerged from the numerous interviews carried out. For further details on the methodology adopted in the field survey see also the following paragraph.
} 


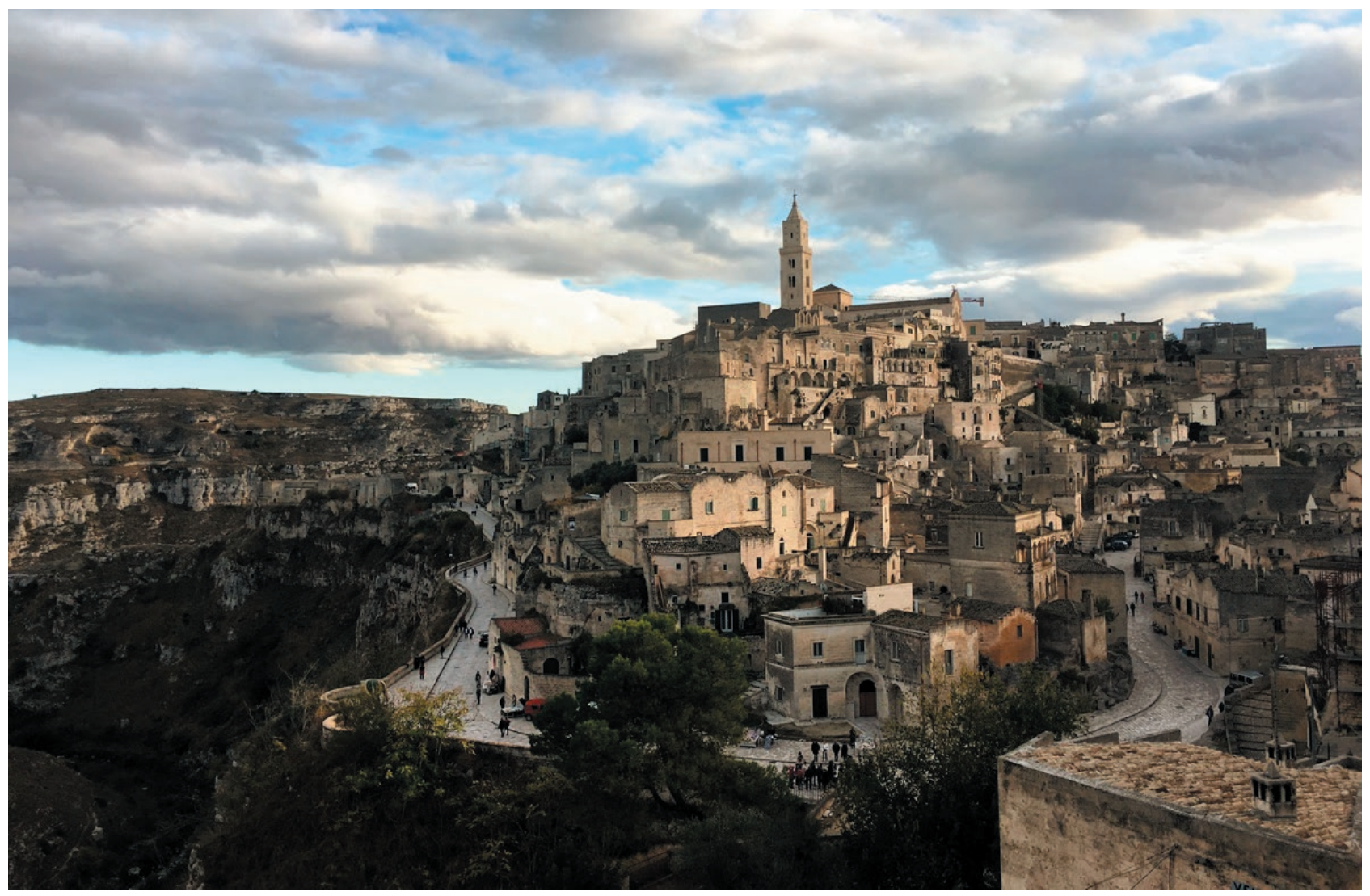

Figure 2. The Rioni Sassi. Source: authors' image, 2019.

\subsection{From the Dante's inferno to tourism paradise}

The historical centre of Matera comprises three main areas: the Civita, the Sassi (Caveoso and Barisano) ${ }^{3}$ and the Piano. Although from an administrative point of view the first two are considered as an unicum, the article specifically refers to the Rioni Sassi.

The district of the Sassi is delimited by the ravine, on whose side it is possible to notice the numerous rocky settlements that characterize the Matera site (Fig.1).

The well-known metaphor, portrayed by "Cristo si è fermato ad Eboli", which compares the shape of the Sassi to the image aroused by the Dante's inferno, really gives

\footnotetext{
${ }^{3}$ The Civita and the Sassi have a considerably different history: the Civita, which houses the Cathedral and the residence of the Archbishop, was originally surrounded by walls and represents the first nucleus of the medieval city, although the first settlements in Matera date back to the Neolithic period (Laureano 1993). The Sassi have developed beyond the limits of the walls, initially with isolated rural buildings, then with clusters of houses and excavated caves inhabited by the humblest part of the Matera population (Giura Longo 1966). Further considerations concerning the commercial organization of the Civita and the Piano are available in Albolino et al. 2019.
}

the idea of the intricate labyrinth of this neighborhood; on the contrary, the living conditions that have shocked Italy no longer reflect the current reality (Fig.2). The unhealthy and overcrowded troglodytic dwellings have been transformed, mostly, into luxury accommodation or restaurants, more or less renowned; the cisterns for collecting water have been converted, in some cases, into elegant SPAs; the humble caves have reached real estate values that far exceed the average of the rest of the city ${ }^{4}$. The traces of rural civilization are now only present in the exposed objects used to embellish trattorias, bed \& breakfasts and house-museums.

In the Fifties, after the enactment of the law 619 of 17 May 1952 for the rehabilitation of the Sassi, the population was relocated to the newly built suburbs, subsequently, the Rioni remained uninhabited for a long time. Only in the Eighties, through two biennial programs (Law 771/86), the Municipality of Matera gave in sub-

\footnotetext{
${ }^{4}$ For further details consult Agenzia delle Entrate, https://wwwt.agenziaentrate.gov.it/servizi/Consultazione/ricerca.htm, last accessed on 20/02/2020
} 
Table 1. Trend of the population of Matera and residents of the Sassi in the period 1950-2019. Source: authors' elaboration from Opendata Matera, various years.

\begin{tabular}{lcccccc}
\hline & 1950 & 1988 & 1994 & 2001 & 2011 & 2019 \\
\hline $\begin{array}{l}\text { Population } \\
\text { of Matera }\end{array}$ & 30.109 & 53.765 & 56.387 & 57.785 & 59.796 & 60.411 \\
$\begin{array}{l}\text { Living in } \\
\text { the Sassi }\end{array}$ & 15.990 & 1.888 & 1.887 & 1.850 & 1.803 & 1.446 \\
\hline
\end{tabular}

concession the houses belonging to the State, allowing the repopulation of the area (Tab.1). This is the moment in which the Sassi loose the connotation of marginality, regaining centrality in the urban fabric. Over the years, the neighborhood has been almost completely requalified, with the exception of a limited part still awaiting restoration, especially in Sasso Caveoso. However, also because of the re-functionalisation in a tourist way, part of the population has left the districts again: 1.446 inhabitants live here in 2019 , with a decrease of $20 \%$ compared to the previous decade $(1.803 \text { in } 2011)^{5}$.

The particular conformation of the neighborhoods also presents problems of accessibility, which is now guaranteed by a city bus line that mainly transports visitors, service claimed for years by the inhabitants to the local administration; moreover, a system of elevators connecting the Sassi and the Piano has been projected. It involved the construction of seven elevators of which only two have been built so far, the first one connecting piazza V. Veneto-Vico Commercio and Sasso Barisano (completed in 2013); and the other one via Casalnuovo and Sasso Caveoso, completed in February 2019, though both not operative yet ${ }^{6}$.

\section{Tourists and commercial activities}

The study of the commercial changes cannot ignore the analysis of the main effects of the tourism, which, in recent times and in different areas, has represented the driver of the urban transformation of Matera.

\footnotetext{
${ }^{5}$ The data reported are the ones elaborated by the municipal bureaus as census data for the Sassi district are not available. The selected years describe a significant trend of the period examined. In 1994, after Unesco World Heritage recognition, 1.887 people lived in the Sassi (out of a total population of 56.387 in Matera). The population remains substantially stable until 2011 (1.803); then there is a progressive reduction until 2015 (1.647), where, one year after the designation of Matera $\mathrm{ECoC}$, the area shows a clear transformation in touristic direction (see Opendata Matera, various years).

${ }^{6}$ In February 2019 the local administration cancelled the operations due to the fragility of the architectural context.
}

In the Nineties, except from some destinations, the Basilicata Region was not well known in national and international tourism circuits; however, in recent time, the presence of a not so well-known environmental and cultural heritage (D'Alessandro 2009) and the incisive action of the Region and the Territorial Promotion Agency (TPA) produced interesting results. Despite the UNESCO World Heritage recognition has been a very important event, tourism in Matera still had not had an important role until ten years ago.

Certainly, the media battage linked to some important cinematographic performances (such as, in 2004, The Passion by Mel Gibson) has had a great effect; then, in 2015, a Financial Times' article brought the image of Basilicata close to Tuscany (Stanzione, Viganoni 2012); some successful films and television series, set mainly in the streets of Rioni Caveoso and Barisano, have caused a significant acceleration of tourist development ${ }^{8}$. Therefore, this has amplified the attention on the Sassi, which have always been the main element of attraction on urban scale.

It should be pointed out that our study mainly focuses on the city of Matera, but the Sassi are undoubtedly the first attractor reached by tourists. Moreover, it is possible to say that the tourist flows directly involve the two Rioni?.

In the period 2000-2009, the city of Matera registered an increment in arrivals of more than $120 \%$ (from about 37.000 to more than 81.000 ), while overnight stays increased by $50 \%$ (Stanzione, Viganoni 2012, 558). Since then, the positive trend continued to grow: overall, after ten years, there is an ongoing increase in arrivals of almost $380 \%$ and touristic presences of around $450 \%$. Nevertheless, here has been analysed the period 20152019, because the designation of the city as European Capital of Culture represented a turning point. This is confirmed by the arrivals and presences trend, exclusive-

\footnotetext{
${ }^{7}$ In these years, the implementation of a specific Integrated Tourist Offer Package and the tourism Plans were examples of quite incisive strategies, policies and actions.

${ }^{8}$ About the tourist enhancement of urban film sets see Nicosia 2012.

9 The data commented here are based on different survey methods, made available by the TPA database, Matera Opendata, the Municipality data catalogue (please refer to http://dati.comune.matera.it/, last accessed on 10/04/2020) and Matera Infocamere, that is the Registro delle imprese created by Camera di Commercio. Useful has been the survey of Datacontact, an important private company based in Matera, that carries out communication and market research activities. Recently it presented an interesting elaboration of the results of over 4.500 interviews about Matera2019, proposed to residents and tourists, face to face and online. We would like to thank Dr. R. Tosto. In order to study the commercial structure of Matera, starting from the overall list of the enterprises registered on urban scale, the data of those located in the streets of the Sassi have been then extracted.
} 
Table 2. The main dynamics related to tourist flows reported in Matera in the period 2015-2019. Source: authors' elaboration from TPA data, various years.

\begin{tabular}{|c|c|c|c|c|c|c|}
\hline & 2015 & 2016 & 2017 & 2018 & 2019 & $\%$ 2015-2019 \\
\hline \multicolumn{7}{|c|}{ Customers movement } \\
\hline \multicolumn{7}{|l|}{ ARRIVALS } \\
\hline Italians & 153.572 & 186.028 & 204.997 & 250.916 & 275.377 & $79 \%$ \\
\hline Foreigners & 61.352 & 64.065 & 76.517 & 93.897 & 112.781 & $83 \%$ \\
\hline Total & 214.924 & 250.093 & 281.514 & 344.813 & 388.158 & $81 \%$ \\
\hline \multicolumn{7}{|c|}{ OVERNIGHT STAYS } \\
\hline Italians & 248.515 & 297.993 & 323.086 & 394.267 & 524.850 & $111 \%$ \\
\hline Foreigners & 105.130 & 111.428 & 124.635 & 153.265 & 205.584 & $96 \%$ \\
\hline Total & 353.645 & 409.421 & 447.721 & 547.532 & 730.434 & $107 \%$ \\
\hline \multicolumn{7}{|c|}{ Accommodation capacity } \\
\hline Hotels & 27 & 26 & 29 & 31 & 36 & $33 \%$ \\
\hline Extra-hotels & 274 & 456 & 556 & 608 & 682 & $149 \%$ \\
\hline Total & 301 & 482 & 585 & 639 & 718 & $139 \%$ \\
\hline Total bed-places & 3.593 & 4.527 & 5.283 & 5.847 & 6.566 & $83 \%$ \\
\hline
\end{tabular}

ly highlighting positive values, registering an increase of more than $80 \%$ in terms of arrivals and $107 \%$ of presences $(\mathrm{Tab} .2)^{10}$.

Significant changes have also affected the typology and the origin of tourists: in recent years the number of foreigners has multiplied ( $+83 \%$ of arrivals and $+96 \%$ of presences), along with national and local tourism that, until ten years ago, represented the almost exclusive category ${ }^{11}$.

According to our work, which focuses on the evolution of commercial activities in the Sassi, the most interesting data concern the accommodation, since the commercial landscape of the Rioni - and in part also of

\footnotetext{
${ }^{10}$ In 2015 the number of arrivals has reached 214.924 units, whereas the number of overnight stays 353.645 ; during the following four-year period, there has been an average annual increase of around $16 \%$ (in terms of arrivals, with a peak of $22 \%$ between $2017-18$ ) and $22 \%$ (presences), reaching the $13 \%$ and $33 \%$ respectively in 2019 . The ECoC year has recorded significant values: about 400.000 people visited Matera (more than 730 overnight stays), preferring the summer months. Additionally, it should be taken into account that the data presented here may probably be underestimated: for some years now, extra-hotel accommodation, especially in the Sassi, seems not to have been systematically acknowledged. As a consequence, even guests of these accommodation facilities might not be included in the census.

${ }^{11}$ If the Apulians are still the prevailing percentage, the Italians who visit the Sassi come mostly from Campania, Lazio and Lombardia (regions that compete for the primacy of this ranking).

Increasingly tourist flows are also recorded from abroad: since 2015 there has been an increase in arrivals (from over 60.000 to just under 113.000 ) and presences (from 105.130 to 205.584). US, France, UK and Germany are the most represented countries, followed by the Netherlands, Switzerland, China and Japan.
}

the Piano (Albolino et al. 2019) - has radically changed in this direction: hospitality activities and food \& drink enterprises represent nearly all the retail businesses located here ${ }^{12}$. In particular, these last aspects concern the Sassi, an area of about 27 hectares, where the development of the total area appears larger, considering that in every little street there are recinti, climbs and stairs and that several houses hide caves and cisterns still unexplored (Fig.3). Here, there is a significant concentration: analysing in detail the streets of the neighbourhoods there are about 300 accommodation facilities, principally extra-hotel activities (there are only 15 luxury hotels) ${ }^{13}$. Moreover, there are 100 accommodations available on the Airbnb website, a third of the overall Airbnb hospitality activities in the city ${ }^{14}$. A similar growth may depend on

12 In 2015 the city of Matera there were 27 hotels (with a total of 1.645 beds) which became 36 (with 2.071 beds) in 2019; more significant is the data relating to the non-hotel establishments: they showed a total increase of almost $150 \%$ (from 274 to 682 , while the number of beds exceeds $130 \%$ : from 1.498 to 4.495$)$. It also emerges that while in the previous years tourists preferred hotels, in 2019 presences were equally distributed.

${ }^{13}$ In fact, there are mainly holiday homes (30\% of those present in Matera are located in the Sassi: 171 out of a total of 546), rooms to rent (56), b\&b (48), one hostel and one holiday home, the first one in the Sasso Caveoso and the other in the Barisano.

${ }^{14}$ In Matera there is a total of 300 Airbnb accomodation facilities. Moreover, Airbnb (https://www.airbnb.it/), created in 2007 and spread in Italy about ten years ago, is an alternative to traditional accommodation. This is a community were the homeowners rent out their houses to tourists. In order to obtain data on the Airbnb accommodation located in the Sassi, it has been identified the precise location of each activity by analysing the website (https://www.airbnb.it/s/Matera--Italy, last accessed on 


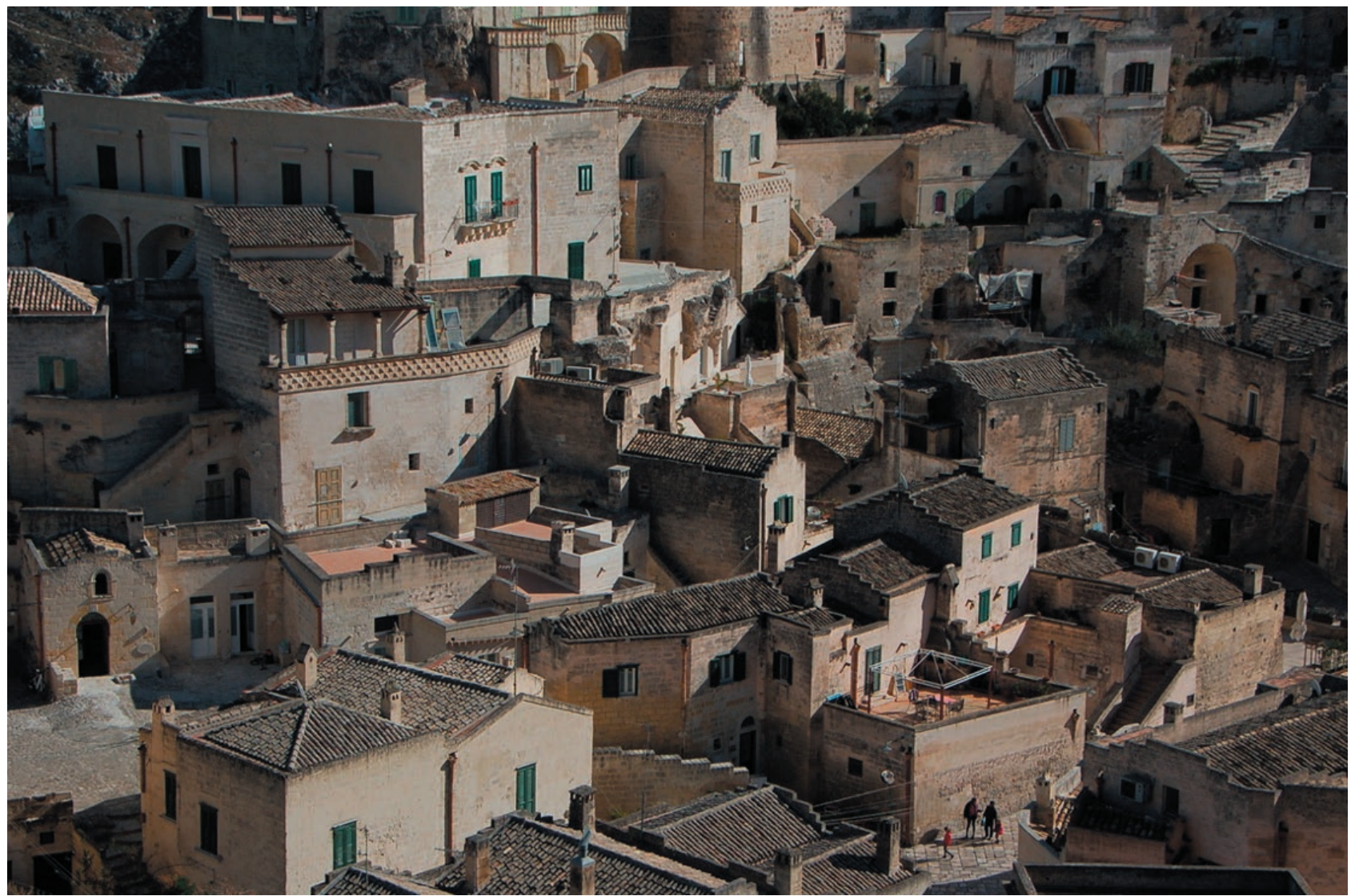

Figure 3. The dense network of narrow streets, recinti and stairs. Source: authors' image, 2019.

the constant improvement in the quality of this type of accommodation offer (as also demonstrated by the Booking.com evaluations), thus presenting an original and more territorialized character, as well as on the flexibility of the offer - which is often characterized by a strong experiential vocation - and by more accessible costs ${ }^{15}$.

Equally significant are the numbers relating to food \& drink activities: due to the specific features they denote, they appear to be a direct consequence of tourism development. The study on the urban area called Piano already showed surprising data, but the analysis of the Sassi reveals the phenomenon extent ${ }^{16}$.

10/01/2020). We also thank Dr. F. Marra for the advices and data provided. The work also revealed a peculiarity: some bed \& breakfasts - this is a fairly limited number - are also proposed on the Airbnb platform. But in these cases they work mainly as b\&b or viceversa. At least so say the hosts contacted.

${ }^{15}$ However, it is clear that the change of these accomodation segments is a direct consequence of ECoC, because only a few hotels were born in 2015 (Sarti 2019).

16 The Opendata Matera website highlights (September 2018) the presence of 76 shops: about $90 \%$ of them are restaurants (43, with a good presence of pizzerias, bracerias, trattorias, with degustation of typical
The data examination of the period 2015-2018 confirms the transformation taking place. During the period under consideration 62 businesses were launched in the Sassi ${ }^{17}$ : excluding accommodation facilities, there are restaurants and delicatessens (34, many of which are also bars $)^{18}$, grocery shops (5, including a bakery and a wine shop, with two of them also selling souvenirs); bars (3, including an ice cream shop and a winebar which is also a rotisserie), a bookshop that also sells gift items. Another 11 shops appear to be linked to the tourist vocation of the districts: specifically, there is a workshop that develops and sells innovative products and services for the enhancement of cultural heritage, a bicycle rental, as well as different activities aimed at storytelling of the modus vivendi of Sassi rural culture, as well as the promotion of events and the organization of exhibitions,

products) and bars (25, including two winebars and a non-alcoholic bar). There are also 8 other grocery shops (activities also carried out by many bars) and an herbalist shop.

${ }^{17}$ See data from Infocamere, March 2019.

${ }^{18}$ And there is also a home cooking business. 
moreover there are artistic handicraft restoration and conservation atelier, and museums ${ }^{19}$. Besides these, there are also the activities of street vendors, recently regulated by the Municipality, who mainly sell typical products and souvenirs, generally of poor quality, in via Madonna delle Virtù.

\section{The Sassi trade}

The main road of the neighborhood starts from via dei Fiorentini and continues with via Madonna delle Virtù up to piazza San Pietro Caveoso, proceeding with via $\mathrm{B}$. Buozzi which leads out of the Rioni ${ }^{20}$. The road, which borders, in the part of via Madonna delle Virtù, the natural limit of the district formed by the ravine, connects the two main accesses to the Sassi, the first one in piazza V. Veneto, and the second one in via Casalnuovo. This street (about 2,000 metres), which interrupts the Escherian perspective of the dense overlapping of caves, houses, narrow paths, steps and squares, follows the bed of the two grabiglioni, watercourses that used to run through the Sassi, interred in 1924 (Giura Longo 1966).

The first phase of repopulation, at the beginning of the Nineties, was not followed - as also confirmed by the above mentioned data - by an adequate articulation of the commercial offer, in particular of neighbouring shops such as bakeries, supermarkets, newsstands, tabacchi, which are indispensable especially because of the peculiar structure and the resulting hard accessibility, in particular for the aged population.

Today, the Rioni are connoted by an evolving commercial landscape: there are increasing numbers of new food \& drink localizations, both on the main roads and in the small squares and secondary streets, alternating local food and more standardized products. Compared to the Piano area, there is a prevalence of restaurants and trattorias with local cuisine, rather than businesses providing street food or take-away. As it was habitual for the inhabitants of the Sassi to use the space in front of the house as an extension of their home, so the restaurant activities also occupy the streets or public squares. Indoor spaces, sometimes insufficient to meet a constantly growing demand, are increased by the tables placed outside, especially during the summer season. As in the Piano area, which has recently seen a crescendo

\footnotetext{
19 They concern, in particular, the setting up of exhibition spaces, aimed at telling Matera and Murgia story, and the bookshop of the exhibition dedicated to Salvador Dalì. There are also 1 shop selling ceramics and various furnishings, 2 film production and filming with drones services. ${ }^{20}$ Via Buozzi and via Madonna delle Virtù are limited traffic areas, while via dei Fiorentini is more accessible by car.
}

of food-related activities, the alternation of dehors often disturbs the perception of the peculiar Unesco site, obscured by umbrellas or more elaborate structures, as well as by groups of tourists waiting for their turn.

A disorderly group of umbrellas also characterizes piazza San Pietro Caveoso, the largest of the Sassi, which hosts several attractions such as the homonymous church, the rocky spur of Madonna delle Virtù and the belvedere from which it is possible to admire a long part of the Gravina torrent and the rocky settlements. In the square there is also the terminus of the urban transport service of the Sassi line. The place, therefore, where via Madonna delle Virtù is followed by via $\mathrm{B}$. Buozzi, gathers a significant flow of visitors and here are present most of the stands selling handicrafts and souvenirs. These are unauthorized traders for this area and in order to rectify this situation the administration has provided a call for fifteen stalls, for the sale of non-food products, in via Madonna delle Virtù ${ }^{21}$, this position, however, is not considered satisfactory by retailers due to the low tourist flow.

The high concentration of tourist and cultural attractions, accommodation activities and restaurants, draws many visitors especially during the day, leaving the Sassi almost desolated in the evening, except on summer weekends. The movida privileges the Piano, in particular the axis that starts from piazza V. Veneto and continues along via del Corso and via Ridola, but at the same time it also gains prestige via delle Beccherie and piazza del Sedile (Albolino et al. 2019). This phenomenon contributes to emphasize the break between the Piano and the Sassi, giving the impression of an entertaining park that can be found in many historical centres intended almost exclusively for tourist use. The standardization of retailscape, moreover, also demotivates the use of the Rioni by the citizens of Matera, for reasons of leisure, who often avoid the restaurants located here due to the rise of prices and who prefer the Piano area for shopping, which although it is increasingly oriented to the tourist demand, is still able to respond satisfactorily to the needs of the residents.

The progressive invasion of the Rioni by commercial activities, mainly destined to the so-called temporary inhabitants, as already mentioned, was followed by the further recent abandonment of the residents who settled here in the Nineties, also due to the lack of basic services.

Currently, the significant flow of visitors has raised the necessity for a medical service and a local police sta-

\footnotetext{
${ }^{21}$ Comune di Matera, Ufficio commercio (04/04/2019) "Assegnazione stagionale posteggi Rione Sassi prodotti non alimentari", http://www. comune.matera.it/avvisi/item/3501, last accessed on 10/05/2020.
} 
tion in the districts, but these, are measures put in place to meet the necessities of tourists, that are the main users of the Rioni nowadays, rather than those of the inhabitants ${ }^{22}$. Following the same approach, it seems to have been issued the last public call for tenders that allows the assignment of buildings in the Sassi ${ }^{23}$ : the Municipality makes available " 17 state property buildings for non-residential use located in the Rioni Sassi meant for neighbouring shops" 24 . Always expected, the presence of retailers of basic products, seems to arrive when the neighborhoods have disappeared, replaced by activities for tourists ${ }^{25}$. The concession of these properties could represent, today, a good opportunity to satisfy the primary needs of the last residents, but the commercial categories mentioned in the public call allow the inclusion of several typologies of products that may not be very useful for the inhabitants but more oriented to the needs of tourists ${ }^{26}$. Considering the high cost for the renovation of the property, which will be covered by the sub-concessionaire, it is conceivable that the investor wishes to take advantage of the echo of the process triggered by Matera2019 to intercept customers that can guarantee greater profits than the sale of bread and milk.

These properties might alternatively have been intended for residential use by singles or young couples (the latter measure provided for by Law 771/86), attempting to balance the phenomenon of tourism tertiarisation and gentrification which has occurred in recent years.

\footnotetext{
${ }^{22}$ Comune di Matera, Settore Opere Pubbliche (29/04/2019) "Verbale di presa d'atto: realizzazione di un presidio sanitario e sede distaccata della polizia locale nella ex scuola materna di Piazzetta Garibaldi", http:// www.comune.matera.it/avvisi/item/3572, last accessed on 09/05/2020.

${ }^{23}$ Following the population displacement from the Rioni, nearly all the houses have been acquired as public property and given in concession to the Municipality of Matera. The two biennial programs for the rehabilitation of the Sassi (provided for by Law 771/1986) have allowed the assignment of the properties with agreed rent for a duration of thirty years. Most of the houses was sub-concessioned in the 1990s. The rent, agreed and paid in advance, was intended, among other things, for the renovation and extraordinary maintenance works to be carried out by the Municipality of Matera (Pontrandolfi 2002).

${ }^{24}$ Comune di Matera, Settore Gestione del Territorio-Servizio Sassi (07/05/2019) "Bando pubblico per l'assegnazione in sub-concessione, per anni 30, di immobili demaniali, ubicati nei Rioni Sassi di Matera da destinare ad esercizi commerciali di vicinato", http://www.comune.matera.it/avvisi/item/3569, last accessed on 09/05/2020.

25 The neighbourhood in the Sassi represented both an architectural and social unit: the contiguity of the houses, opened around the small square or a courtyard, allowed the natural relationship between the inhabitants, that strengthen their social relations outside the door of the house.

${ }^{26}$ Such as the sale of travel items and souvenirs, antiquities, modelling items, art galleries, paintings, sculptures and graphics with historical and artistic value, furniture and objects with historical or artistic value,
} philatelic items, numismatic items and other collection items.
It should be remembered that the State property, conceded in the Nineties at an agreed rent, envisaged an amortisation plan for restructuring costs. At present, the sub-concessions do not determine appropriate revenues for the administration, which in the meantime has to face the expenses for the ordinary maintenance in the Sassi, significantly increased, also because of the commercial activities established here and the high number of tourists ${ }^{27}$.

In the Sassi there is a considerable part of the public building heritage of Matera and to this must be commensurate the financial resources for the maintenance that cannot be covered by the property rents which are highly inadequate both at current costs and at market prices. Moreover, the significant presence of accommodation, restaurant and commercial activities turn out to be a source of conflict, not only with the residents, whose quiet is disturbed, but also among the operators themselves, whose needs are often divergent (noise coming from pubs and restaurants close to bed \& breakfasts).

\section{Opinions and perceptions from the interviews with the people who live the Sassi: some conclusive considerations}

It is clear that as a direct consequence of the tourist flows described, the Sassi district, especially in recent years, has strongly invested in conversion of its commercial spaces, concentrating them on all types of accommodation and food \& drink activities. The research points out that, except for rare exceptions, the businesses aroused as a result of the designation, today belong to these two categories, aimed almost exclusively at tourists, while there are no essential shops needed in a residential area.

It should be noted here that the proposed study is the result of a detailed series of interviews (supporting the desk analysis), addressed to the witnesses of the dynamics in progress, that we consider privileged mainly because they are historical residents of the Rioni, because of their work (they are owners of entrepreneurial activities) or because they are representatives of the institutions.

This has been done in order to replace the planned field survey: it was opted for interviewing people who have a good knowledge of the places, so as to obtain

27 This is also what emerges from the interview with M. Morelli. The collection of waste, for example, implies high costs due to the peculiar morphology of the districts that does not allow simple operation of motorized vehicles and therefore requires a number of people that carry out the work manually. 
adequate descriptions of the actual situation. The inhabitants were asked about the living conditions in the Sassi ${ }^{28}$; to the others, especially entrepreneurs, we asked about the main changes occurred in terms of tourism and the critical issues identified, from the designation to the end of 2019, also inviting them to provide an overall assessment of the year of the event and possible future perspectives ${ }^{29}$.

The economic motivation of the ongoing transformation is clear but it seems to be paradoxical e and source of numerous problems ${ }^{30}$. A further complication is represented by the difficulties - aggravated by the problems of accessibility - to inhabit an environment that is already considered complex from an architectural point of view.

Tourism in the Sassi has de facto altered the functional structure of this residential area which is being transformed into a cultural asset, mainly available to tourists rather than its inhabitants. Moreover, it appears evident that the declared residences would may hide the high density of b\&b, holiday homes and apartments of the Airbnb network. It is no coincidence that in via Casalnuovo, which is one of the streets with the highest concentration of residential properties, there is also a huge number of extra-hotel accommodation activities ${ }^{31}$.

The application dossier for ECoC also defined the

\footnotetext{
${ }^{28}$ Due to the architectural difficulties, problems of accessibility and the lack of primary services (commercial and non-commercial).

29 The analysis was based, therefore, on the results of the forty qualitative interviews with residents and, more generally, with city users, carried out in loco (which turned into telephone interviews during the lockdown), as well as on the results of Datacontact's research (see note 9) and on the direct knowledge of the places: the authors have been working in Matera for several years. We would like to thank all those who have shown great availability and attention to our research in a difficult time. Among others A. Antodaro, G. Armando, A. Bonora, V. Corleto, D. Coscia, A. Esposto, L. Paolicelli, T. Mariani, R. Montinaro, M. Morelli, F. Ponte, A. Pontrandolfi. For convenience reasons here are present only some notes on the opinions expressed by the many people interviewed.

${ }^{30}$ For many, after the initial enthusiasm, the turning point expected with the ECoC has betrayed expectations: "the real change" has stopped at the edge of the Sassi. Some have even spoken of a substantial deterioration in the quality of life for the inhabitants: invasion of tourists; noisy nightlife; maintenance and cleaning concentrated in the main streets; lack of parking; a shuttle bus, set up by the Municipality, which follows a route considered not useful for residents; many restaurants with high costs ("it is not possible to buy a sandwich or simply some bread", "a greengrocer's shop would also be important for tourists, not only for residents"). And there is a sort of marked break point with the rest of the city (it is used to say "go up to the Piano, go up to the city").

${ }^{31}$ And the same happens in via Buozzi, via Fiorentini and San Pietro Caveoso. According to the interviewees, especially residents, this happened with the more or less explicit approval of the institutions that in the Sassi have favoured the establishment of the accommodation activities and privileged the needs of restaurateurs over those of the inhabitants, punctually expressed also by the Committee of Rioni Sassi Neighborhoods.
}

tourists as "temporary citizens": active participants in a long-term "civic project" based on mutual learning, creativity and shared values. Well, it does not seem that the "civic project" mentioned above, the strategy that becomes action by involving citizens, has been fully implemented.

Throughout the year of events Matera 2019 the volunteers were so many, but often the inhabitants of the Sassi, rather than being protagonists of a kind of "greeter destination" (Holmes, Smith 2009) ${ }^{32}$, were relegated to the background, as it has been happening for years: the neighborhood has strengthened its role as cultural attractor but according to many viewpoints the ECoC event has excluded residents from the decision-making processes $^{33}$. This is the opinion expressed by the majority of those who are engaged in hospitality and food \& drink activities, but who often do not live there ${ }^{34}$.

Beyond the importance of the event, in the Sassi it seems to be the awareness that a process based on cultural heritage, on its fruition associated with innovation, has produced intervention of urban regeneration but has failed to ensure in general a better quality of life for residents. Probably - with the exception of neighbourhood relations and the sense of pride for the realized events - the sense of belonging and participation has not been strengthened ${ }^{35}$

The commercial landscape, lacking essential services, seems to confirm this, although it is aimed at socalled "temporary citizens". But if the tourist becomes the only actual resident, this process will probably lead the place to turn into an entertaining park at worst, or

${ }^{32}$ For this particular type of tourist hospitality and participation of local communities please also refer to https://globalgreeternetwork.info/, last accessed on $14 / 05 / 2020$.

${ }^{33}$ This is what has been said several times by the inhabitants involved; however, even entrepreneurs report such difficulties, although they are less critical about engagement issue, charging it to individuals rather than to the administration, and sometimes complain about the need for greater autonomy. On Matera2019, however, the opinions of economic operators are decidedly positive, although some point out that "it could have been done better and earlier"; there are also those who note the absence of programming aimed at "after 2019".

${ }^{34}$ One of the historical residents said: "they are not real Sassi inhabitants". It should be underlined, however, that this is not always the case: some entrepreneurs have launched accommodation activities inspired by the so-called responsible tourism and consider them not only an economic activity by itself but also the possibility of meeting people, sharing experiences, opening up to the outside world a reality as rich in history as the Sassi. And actually the "tourism of emotions" is the real future prospect.

${ }^{35}$ It emerges, in fact, the enthusiasm of the people of Matera for the goal achieved, but at the same time more than $80 \%$ defined themselves as spectators rather than protagonists of the multiplicity of projects put in place; moreover, the $40 \%$ asked for a greater involvement of citizens in the upstream organization of cultural initiatives (Datacontact 2020). The same happens in our interviews. 
rather into a commercial showcase, resulting in the expulsion of its inhabitants, as Magnaghi (2017) argues about Alberobello ${ }^{36}$.

This also refers to the typical products, so much requested by tourists. In the Sassi there was the bread making tradition: after the sfollamento no trace remained (Fadini 2012). The absence of commercial activities aimed at local consumption also risks erasing what could be a closer link between the tradition of the places and the tourism development.

There is no doubt that many criticalities are also to be attributed to the peculiar topography and historical evolution of the Sassi, but it seems to emerge the need to intervene concretely and in a more focused way.

Also because, in the meantime, the pandemic has opened totally unpredictable scenarios that will have to be tackled through shared strategies and multiscale policies.

In order to better manage the processes of tourism and gentrification of the Sassi area, it seems advisable to have a significant commitment of the institutions in different directions. It emerges mainly the need to promote more participation and communication campaigns, probably also through a greater connection with the Rioni Sassi Committee: the good aggregation capacity of local associations in the Sassi is really important; this should be combined with the need to coordinate more effectively the influx of tourists, especially those who do not stay overnight and that sometimes turns into the most deleterious bite and run tourism. From this point of view, it might also be necessary to update the framework of regional tourism planning, also considering the most recent events, so as to be able to respond to the changing needs of the territories and populations, with particular attention to the new role - which must be recognized and consolidated - of the internal areas ${ }^{37}$. This may prevent further conflict situations in the future.

These are only some of the aspects to consider, but, more generally, in a climate of strong uncertainty (although positive attitudes are not absent) there is the need to define as soon as possible a strategic programme, intended as an organized and coherent response is required, that involves all the actors present

\footnotetext{
${ }^{36}$ It is no coincidence that in the survey of Datacontact, in response to the question of how Matera became after the candidacy, the adjectives "international" and "famous" are highlighted, but $80 \%$ also adopt the expression "more commodified".

${ }^{37}$ One of the objectives, in extreme synthesis, is to promote forms of diversification of tourist flows. This would allow to encourage a rebalancing of the provincial and regional tourism development in favor of contexts that can be transformed into privileged destinations of a more sustainable tourism; at the same time, it could be envisaged the visit to the Sassi in a more suitable way adapted to the specificity of the place (thus also ensuring the coexistence of residential and tourist functions).
}

in the area and promotes the key actions to tackle the situation being experienced.

\section{References}

Adamo, F. (Ed.). (2012). Turismo e sviluppo urbano in Italia. Bologna, Pàtron Editore.

Albolino, O., Cappiello, L., Iacovone, G., Stanzione, L. (2019). Profitto e valori: ethos e commercio. Il caso di Matera. In Viganoni, L. (Ed.). Commercio e consumo nelle città che cambiano. Napoli, città medie, spazi esterni. Milano, FrancoAngeli, 149-192.

Cirelli, C. (Ed.). (2007). Gli spazi del commercio nei processi di trasformazione urbana. Bologna, Pàtron Editore.

D’Alessandro, L. (2009). Le nuove geografie del turismo. Le prospettive del settore in Basilicata. Bollettino della Società Geografica Italiana, serie 13, 2 (4), 925-937.

D’Alessandro, L. (Ed.). (2015). City, Retail and Consumption. Napoli, Università di Napoli "L'Orientale".

D’Alessandro, L., Stanzione, L. (2018). Scale, dinamiche e processi territoriali in vista di Matera 2019: riflessioni su sviluppo locale, cultura e creatività. Geotema, 38, 78-90.

Datacontact (febbraio 2020). Matera 2019. Il vissuto del 2019 e l'eredità della Capitale Europea della Cultura. Il punto di vista di turisti e residenti. Matera, Datacontact.

Fadini, S. (2012). Turismo e rilancio dei prodotti tipici. Il pane di Matera. In Picciotto, L., Ruisi, M. (Eds.). Atti della IV Riunione della Società Italiana Scienze del Turismo (SISTUR). Roma, Aracne Editore, 165-176.

Finkelstein, J. (1999). Foodatainment. Performance Rese$\operatorname{arch}, 4$ (1), 130-136.

García, B. (2004). Urban regeneration, arts programming and major events: Glasgow 1990, Sydney 2000 and Barcelona 2004. International Journal of Cultural Policy, 10 (1), 103-118.

Giura Longo, R. (1966). Sassi e secoli. Matera, Galleria studio.

Holmes, K., Smith, K. (2009). Managing Volunteers in Tourism: Attractions, Destinations and Events. Oxford, Elsevier.

Kärrholm, M. (2012). Retailising Space. Architecture, Retail and the Territorialisation of Public of Public Space. Farnham, Ashgate.

Laureano, P. (1993). Giardini di pietra. I Sassi di Matera e la civiltà mediterranea. Torino, Bollati Boringhieri. 
Magnaghi, A. (2017). Pianificazione, territorio, cultura. In Mininni, M. (Ed.). Matera Lucania 2017. Roma, Quodlibet, 297-299.

Nicosia, E. (2012). Cineturismo e Territorio. Un percorso attraverso i luoghi cinematografici. Bologna, Pàtron.

Pontrandolfi, A. (2002). La vergogna cancellata. Matera, Altrimedia.

Richards, G., Palmer, R. (2010). Eventful Cities: Cultural Management and Urban Revitalisation. Oxford, Butterworth-Heinemann.

Sarti, M. (2019, febbraio, 12). Matera 2019: un riconoscimento che viene da lontano. https://www.jobintourism.it/ news/matera-2019-un-riconoscimento-che-viene-da-lontano/, last accessed on 15/04/2020

Semi, G. (2015). Gentrification. Tutte le città come Disneyland?. Bologna, il Mulino.

Stanzione, L. (2009). Prefazione. In Stanzione, L. (Ed.). In Basilicata. Guida alle escursioni. $50^{\circ}$ Convegno nazionale dell'Associazione Italiana Insegnanti di Geografia (Potenza, 19-23 ottobre 2007), Bari, Edizioni di Pagina, 7-9.

Stanzione, L., Viganoni L. (2012). Il turismo nella "Città dei Sassi”: un fenomeno recente. In Adamo, F. (Ed.). Turismo e sviluppo urbano in Italia. Bologna, Pàtron, pp. 571578.

Viganoni, L. (Ed.). (2017). Commercio, consumo e città. Quaderno di lavoro. Milano, FrancoAngeli.

Viganoni, L. (Ed.). (2019a). Commercio e consumo nelle città che cambiano. Napoli, città medie, spazi esterni. Milano, FrancoAngeli.

Viganoni, L. (2019b). Il progetto di ricerca: approcci teorici ed evidenze empiriche. In Viganoni, L. (Ed.). Commercio e consumo nelle città che cambiano. Napoli, città medie, spazi esterni. Milano, FrancoAngeli, pp. 149-192. 